\title{
Libya After Qadhafi: Reshaping the Political and Security Systems
}

\author{
Wolfgang Mühlberger *
}

\section{Introduction}

The fall of Muammar al-Qadhafi in October 2011 marked the end of the Libyan uprising, led to the close of NATO's intervention "Operation Unified Protector" (OUP), and ushered in a delicate political transformation which failed to come to a quick and decisive end with the first round of elections held in early July 2012. To assess some major pitfalls of the current transitional process, this article will propose an analysis of two main challenges the new Libyan authorities will face, the proper handling of which will determine the nature and stability of the future state. The first challenge is the political transition from an autocratic regime via revolutionary credentials to democratic legitimacy. The second involves the construction and governance of an entirely reshaped security sector, both in the military and civilian realms, transcending their previous roles in the Jamahiriyya either as Praetorian Guard or as state-sponsored bullies. ${ }^{1}$

Libyan politics are not immune to the major novelty introduced by the Arab Spring. Political representation transformed into a reflection of forces on the ground: what used to be called in derogatory terms the "Arab Street"- as opposed to the will of the dictator, or alleged Western interests - morphed into public opinion, which was now suddenly relevant in elections. Yet the first free national elections in Libya produced a mixed picture without clear majorities, partially due to the complicated electoral system, which was split into party lists and individual candidates. Furthermore, as could also be witnessed in local elections that took place in Misrata and Benghazi, political Islam as such seems not to be favored by the Libyan people. This means the search for charismatic, authoritative political leadership during the transition phase will most likely continue. However, achieving stability cannot be attained by a successful political transition alone. Rivalries between numerous and relatively autonomous kata'ib (militias) could degenerate into open confrontation. ${ }^{2}$ If those rebel commanders, who have suddenly transformed into politicians, lose in the elections where they sought to acquire democ-

\footnotetext{
Wolfgang Mühlberger joined the Austrian National Defence Academy as a Middle East expert in 2009, first as a freelancer then as Senior Researcher MENA. His interests cover Islamism/ Political Islam, the Israeli-Arab conflict and, more generally, Arab intellectual history. This paper is the result of a fact finding mission in Tripoli in June 2012 and of a research fellowship granted by the NATO Defense College (from April till July 2012). He also is the author of a monograph on progressive Muslim reformers and is currently researching on the reconfiguration of the Islamist landscape in North Africa for his PhD.

1 Colonel Muammar al-Qadhafi coined this neologism to give a name to his "Republic of the masses."

2 I prefer to render katiba/kata'ib (singular/plural) as militia (instead of brigade), thus underscoring these groups' irregular character and limited size.
} 
ratic credentials (and in the process to transcend their previous revolutionary achievements as militia leaders), such a scenario becomes more likely.

The National Transitional Council (NTC) and its interim government have prioritized security sector and judicial reform from the very beginning in order to provide for a smooth transition in post-conflict Libya. However, in the current climate justice seems mainly to be understood to consist in indicting former regime officials (such as Qadhafi's son Saif al-Islam or the former Prime Minister Baghdadi al-Mahmoudi), rather than in terms of conducting reforms of the justice system. Simultaneously, assassinations are not uncommon. Jumma al-Jawzi, the judge who ordered the arrest of Abdelfattah Younes (commander of the National Liberation Army since his early defection, assassinated in July 2011) was killed in June this year. ${ }^{3}$ Several candidates running in the recent elections or former Qadhafi-era office bearers have been victims of politically motivated murder or assassination attempts as well.

Despite the NTC's rhetoric about national reconciliation, security sector reform (SSR) is making slow progress in an environment that is prone to the settling of old intertribal disputes. These tribal rivalries, which had been used by Qadhafi as a reliable mechanism to consolidate his power, are now free-floating in the absence of a central authority. Practically, mediation efforts for the implementation of fragile cease-fires tend to be undertaken by shuyukh (tribal leaders), elders and notables from influential families. The army claimed on several occasions to have dispatched contingents to intervene in tribal clashes, such as confrontations in southwestern Sebha or southeastern Kufra. The reality looks quite different. In the case of Kufra, where black Tubu tribal members have been fighting against Arabs for the control of smuggling routes, the locally predominant Arab Zuwayy tribe was put under a command structure of the Libyan Army, named Libyan Shield Forces. ${ }^{4}$ In this way, not only is the fox put in charge of the henhouse, but Qadhafi's policies of Arabization are perpetuated upon other terms.

Officially, one of main responsibilities of the Ministry of Defense is the integration of rival militias into the armed forces. But practical challenges, such as the ministry's negative image, more attractive job alternatives, and the reluctance of the institution itself to welcome former irregular rebels inside its walls, impinge on this element of the process of security sector reform. In addition, Libya's border guards - a crucial element of the security landscape - went on strike on the nation's eastern border with Egypt to protest their dangerous working conditions, due to regular shooting attacks by smugglers.

Overall, at this early stage in the post-conflict era, the impression remains of various interim bodies delegating security provision to localized militias, whereby they either further entrench the groups in the extra-legal realm or, ideally, prepare them for a role as

3 Libya: Rule of Law or Rule of Militias? (London: Amnesty International, July 2012); available at http://www.amnesty.org/en/library/asset/MDE19/012/2012/en/f2d36090-5716-4ef1-81a7-f4 blebd082fc/mde190122012en.pdf.

4 Nicolas Pelham, "Rivalries for Authority in Libya," NOREF Report (7 June 2012); available at http://www.peacebuilding.no/Regions/Middle-East-and-North-Africa/Publications/Rivalriesfor-authority-in-Libya. 
official security providers under the aegis of the Ministry of Interior. The establishment of the SSC (Supreme Security Council) is a positive example of the latter: an officialand functional-umbrella organization that can help incorporate former thuwwar (revolutionaries/rebels).

The overarching goal for European security policy, in terms of NATO policies as well as from a CSDP perspective, will be to avoid a failed-state scenario that would lead to Yemeni- or Somali-style fragmentation on the southern shores of the Mediterranean. To pre-empt this worst-case scenario, Europe must address the situation in Libya with urgency and wisdom, mainly through providing political support for the newly elected government. Eventually, this boils down to working to avoid a situation that could entail a ground forces intervention with both peace-making and peace-keeping elements. Such a scenario would not only embolden domestic militant Islamists (such as the LIFG $^{5}$ ), but could even trigger the fervor of global jihadis. Currently, such a worst case seems quite unlikely. However, any further deterioration of the security situation in the Sahel zone, which in the end represents a cordon sécuritaire for Europe, could also adversely affect the state-building process in Libya.

Most probably, the expected return of the oil-based rentier state will allow the state to reinforce central authority via its distributive role. Expectations regarding the largesse of such a patrimonial state continue to exist, which will provide the next elected government with formidable leverage. The state's tremendous financial clout might turn out to be the single most convincing tool to co-opt pragmatic forces, and should even enable the authorities to rein in unpredictable elements (like rogue militias) on the path towards state building.

NATO should use the positive momentum created by OUP in Libya and engage in enhanced cooperation with the newly elected government and the leadership of the new national army. At the same time, uncertainties persist. Will the results of the political transformation eventually create sufficient political desire on the Libyan side to reciprocate the offer for cooperation formulated at NATO's Chicago summit in May 2012? The door for Libya's integration into the Mediterranean Dialogue (MD) stands wide open. However, given that Tripoli has a yet-to-be-defined geopolitical orientation, the potential for joining a new "non-aligned movement" under Muslim Brotherhood guidance, and a strong tendency towards nationalism and autonomous action based on considerable resource wealth, the scope and quality of the future NATO-Libya relationship remains a question mark.

\section{An Evolving Political Landscape}

Since Qadhafi's fall from domestic and subsequent international grace - and eventually from power, with NATO's indirect support - two interim authorities have been set up. The NTC and its provisional government were organized by a range of political pragmatists to represent Libya to the outside world and to coordinate an ambitious domestic road map towards political participation, democratic legitimacy and, tentatively, post-

5 The Libyan Islamic Fighting Group, led by Abdelhakim Belhaj. 
conflict reconciliation. These pragmatists shared the goal of opposing Qadhafi's authoritarian rule and vied to succeed the Jamahiriyya system. Yet, the new political actors hail from widely differing ideological backgrounds. Having achieved their shared goal-i.e., ending Muammar Qadhafi's regime-the NTC and the nominated (not elected) interim government under Prime Minister A. al-Keib could not paper over the presence of a heterogeneous opposition, and thus found themselves in the brave new world of democratic pluralism. Against this backdrop, the quality and viability of the new political system will depend on the level of cooperation between antagonistic forces. ${ }^{6}$

The interim bodies have both repeatedly been criticized for their lack of legitimacy, transparency, and accountability. First, being a self-proclaimed body representing the bulk of the opposition enabled the NTC to acquire substantial international acceptance, and to gain political as well as military support from abroad. At the domestic level, its authority was either questioned in principle, due to its lack of democratic credentials, or was criticized due to uneven regional representation, supposedly favoring the eastern Cyrenaica region. Second, the fact that opacity persisted around the set-up of the body (the NTC members' list was taken off the website) supported the argument of those clamoring for increased transparency. Lastly, the lack of potential accountability was raised in relation to the two other points. Criticizing a hastily-formed interim body based on the concerns outlined above might appear somewhat exacting to the external observer. On the other hand, against the backdrop of forty-two years of highly arbitrary and unpredictable rule, the desire to establish genuine democratic participation is certainly understandable.

Nevertheless, in the challenging environment of post-conflict Libya, the NTC has been successful in setting a course for local and nationwide elections. The obvious aim of the election process is twofold: ending the temporary dual power structure (NTC and interim ministers) put in place by the pragmatists of the 17 February Revolution, and enabling a popular vote to legitimize a new government. Yet one of the biggest challenges will be to overcome the widespread lack of trust toward representative power. This is less an issue regarding the NTC per se, but one with deeper roots, stemming from resentment towards centralized power that built up over decades. Furthermore, the principle of democratic political representation still has to be appreciated in Libya in its full meaning. Polls have shown repeatedly that the rationale of political parties needs to be conveyed to the public at large more effectively; for voters who have never cast their ballot, or even less thought about choosing between political alternatives, the learning curve can be steep.

In addition, elections should also function as a mechanism to overcome a parallel power structure that currently is still in place. With the start of the uprising and the ensuing civil war, the population became organized on the grass-roots level. As a result,

6 For a detailed description of centripetal vs. centrifugal forces refer to Arturo Varvelli, "Evoluzione della situazione in Libia," Osservatorio di Politica Internationale: Approfondimento ISPI (May 2012). 
local government and military councils were set up to manage the uprising and to create strongly localized safety networks. These local councils will either get re-elected in local elections, or will try to represent the interests of their constituencies via participation in the nationwide elections for an individual seat in the national assembly. Therefore, the possibility cannot be ruled out that the new National Assembly (renamed the General National Congress) will less represent the interests of various social strata, but rather will function in 'localized' terms. This trend could even be facilitated by the larger number of seats for individual candidates (120 of 200) versus party list seats (80).

Generally speaking, groups vying for representation in the new political system include a wide range of revolutionary and post-revolutionary actors: pragmatists (who chose politics over warfare from February 2011 onwards); militia leaders; Islamists (covering the entire spectrum, from parties with basic references to Islamic ethics via the Muslim Brotherhood to more radical forms of ideology-based movements); tribal sheikhs, including some former Qadhafi loyalists; and federalists.

The Muslim Brotherhood faces a triple challenge in the Libyan polity. First, political Islam as such faces fundamental opposition, since the idea of setting up a political party solely based on a variant of Islamic ideology raises doubts (if not outright suspicion) among Libyans. ${ }^{7}$ Second, quite to its disadvantage, the Brotherhood has the flavor of an Egyptian movement, due to its historic origins in the neighboring country, a quality that is even more pronounced now that the Muslim Brotherhood is formally in power in Cairo. Finally, the Ikhwan were not a very visible part of the Revolution, despite their representation in the Benghazi-founded NTC. But their strategic advantage is of a different nature. Abdellatif Qarmoos, head of the Majlis ash-shura (consultative council), convincingly argued that the Muslim Brotherhood is able to deploy a broad network covering the entire country, providing them with strong outreach to convince and mobilize voters. This could turn out to be a decisive advantage compared to other political parties, who tend to be organized on a more local level. The real fight for political predominance can thus only occur between parties with either countrywide presence or those that appeal to the large urban populations along the coast.

In order to counter federalist tendencies in Cyrenaica, the NTC proposed to decentralize power away from Tripoli by setting up certain ministries (such as the ministries for oil or the economy portfolio) in Benghazi. This method could be an option to preempt efforts towards a regional split or a bid for autonomy in a breakaway Eastern Libya. Yet, the entire federalism vs. autonomy 'debate' in Cyrenaica seems to be much less a cover-up for achieving full-fledged independence than a means to translate the strong urge of the region to end the marginalization experienced under Qadhafi. In a first move after the 7 July elections, Ahmed Zubair al-Senussi, the leader of the CTC

7 A general reference to Islamic values, however, is a must for all parties. In the first nationwide poll conducted post-Qadhafi, 57 percent of the respondents said that the Muslim Brotherhood should play no political role. For poll results, see http:/www.prnewswire.com/news-releases/ university-of-oxford--national-public-opinion-poll-of-libya-139308408.html. 
(Cyrenaica Transitional Council), positively replied to a call for national unity by Mahmoud Jibril, head of the winning National Forces Alliance (NFA).

During the last week before the first free election, the Grand Mufti of Libya, Sadiq al-Gharyani, called upon people to vote according to their conscience. In this way he was clearly alluding to "Islamic" conscience, and thereby endorsing a vote for more strictly Islam-based political groups. In another last-minute action he even issued a fatwa decrying the lack of Islamic references or principles of various political parties, including the NFA.

\section{Elections and Political Culture}

The last time multiparty elections took place in Libya was in 1952, to elect the parliament of the recently founded United Kingdom of Libya. Yet later in the same year, King Idris al-Sennusi prohibited elections and the democratic party system in order to consolidate his authority within the constitutional monarchy. With Qadhafi's Revolutionary Command Council (RCC) coming to power in a bloodless coup in 1969, initially a single-party system was set up (the Arab Socialist Union) that quickly dissolved to make place for a political system of various lineages, including some Maoist inspiration. ${ }^{8} \mathrm{~A}$ fictive "basic democracy," expressed through basic popular councils-whose main task was to rubber-stamp decisions previously made by the Murshid, the leader, thus creating a bottom-up appearance-was kept at bay through a scope of action that was strongly restricted by the Revolutionary Committees, thus fiercely ensuring the permanence of the Green Revolution. Therefore, it is no wonder that buildings of the (armed) Revolutionary Committees, alongside those of the security apparatus, were among the first victims of arson attacks and looting when the uprising began in Cyrenaica in February 2011.

Over the years the Colonel had a tendency to refrain from direct political involvement, limiting himself to two official positions: head of the armed forces and leader of the revolution. This allowed him to skillfully maneuver his policies from the rear, and to continue his propaganda against the 'wickedness' of political parties. Hence elections, such as the one on 7 July 2012, represent a complete novelty in Libya, and mark a cornerstone of fundamental importance for the rebuilding of a new political system. Initially set for 19 June, the HNEC (High National Election Committee) decided to postpone the polling. Among the many reasons given, the cumbersome and time-consuming vetting of candidates certainly played a major role in the decision.

Interestingly enough, the political culture of the Jamahiriyya is still alive through lessons learned from the Qadhafi system: during the upheaval, a pattern of locallyrooted councils emerged in basic-democratic style and handled the fragile transition. Thereby, in an almost ironic twist of fate, the call of the late Qadhafi to his people to set up so-called "popular committees" throughout the country seems to have seen the light only once he left the political scene.

8 Hugh Roberts, "Who said Gaddafi had to go?," London Review of Books 33:22 (17 November 2011): 8-18; available at www.lrb.co.uk/v33/n22/hugh-roberts/who-said-gaddafi-had-to-go. 
The roadmap to democratization and for the expression of popular will is intended to be a process. The NTC announced these consecutive steps at a very early stage- - long before it moved from Benghazi to Tripoli- to underscore its role as the facilitator of the transition. In detail, the initial schedule was as follows: elections for a national assembly, followed by the nomination of an elected government; elaboration of a constitution, eventually to be confirmed via referendum; and elections (planned for 2013) based on the agreed constitution, which will finally allow the nation to put in place a non-temporary government. ${ }^{9}$

The General National Congress (parliament) will comprise 200 seats, of which 80 will be distributed between candidates from party lists, and 120 - assigned to individual candidates. This distribution is based on population density figures according to the 2007 census. In order to circumvent additional criticism from Cyrenaica, the NTC announced that seats in the constitutional assembly, consisting of 60 MPs, will be distributed equally among the three main regions.

The vetting process eventually endorsed 1200 candidates running for party lists, and 2500 running as independents. Based on these results, as well as on the activities of political actors, candidates in certain towns will either run as individuals or for party lists. Also, even though an impressive number of parties registered (more than 140), only a few will run on a national basis (i.e., in every voting district). In other words, taking into account the strong element of individual candidates, the election results will more likely reflect local polling patterns, rather than an abstract "national interest" or a party platform defined by a particular political group.

In practice, there are only two ways to overcome this tendency. The first option is to become an ideology-based movement (like the Muslim Brotherhood), which purportedly serves shared interests or values that extend beyond tribal, parochial, or strictly regional considerations. The second option is to set up a broad alliance of smaller (locallyrooted) parties under the umbrella of a single, more or less unifying party symbol. This option was chosen at an early stage by Mahmoud Jibril, previously interim Prime Minister of the NTC and now head of the victorious NFA.

Given this complex environment of vetting procedures and party registration, along with a voter registration system that managed to include 80 percent of Libya's 2.7 million eligible voters, the preparations turned out to have been successfully managed by the NTC/HNEC (and reflected obvious enthusiasm among the population). On Election Day, a voter turnout of roughly 1.6 million voters, a total corresponding to 62 percent of registered voters, gave proof that Libyans were eager to support the new political system in the making. The NTC, whose Chairman Abdeljalil had made a similar announcement after the end of the civil war, reiterated its stance on the future role of sharia (Islamic law) on the day before the polling went ahead. According to this transitional body, which will not play any politically relevant role after its dissolution, Islamic law should

9 Shortly before the elections, the NTC decided to change the way the constitutional committee should be set up in order to calm criticism from the eastern region regarding the distribution of seats. This decision is now being put into question by the National Forces Alliance. 
be the main reference for law making in Libya, a status that should be enshrined in the future constitution. In its view, this recommendation should be taken into consideration by the next government, and the question should not be subject to a popular referendum. However, any new constitutional proposal, with or without sharia references, will be put to a referendum in accordance with the roadmap for democratization.

A few final remarks should allow for a more complete picture of the ongoing political transformation process. Despite fears (and many resulting announcements), major disruptions of the elections did not materialize. The so-called federalists of the CTC lacked sufficient mobilization power to enact a large-scale boycott of the election, and hard-core Salafis prefer to target sites of religious importance, such as graves of Sufis (who are considered heterodox), instead of disturbing the ballot. Eventually, the elections took place undisturbed in virtually all districts.

Nevertheless, the election results might still be challenged violently by rogue groups, who do not see their own interests represented sufficiently by the results, or by those who hold that the winners with former ties to the regime are unfit to lead the country. This criticism has already been raised against M. Jibril, including by the Grand Mufti, who claimed that, if Jibril were to come into office, it would constitute a theft of the revolution. In the end, the numerous individual candidates - who will hold the majority of seats (120) in parliament - could turn out to be the real kingmakers.

\section{The Tribe-State Relationship: Local Tribal Governance?}

Compared to other North African states, Libyan society is decidedly organized much more along tribal and clan lines. ${ }^{10}$ Yet this type of societal organization is challenged by the presence of a long-standing urban citizenry, as well as by large segments of the nation's youth. But kinship ties continue in urban centers, too, where they often play out in so called "extended family politics" and sometimes have an impact on the composition of city quarters. More important, though, is that the relationship between tribal patterns and state institutions is not antagonistic, but rather complementary and overlapping. This particular Libyan reality should be taken into consideration by every external actor engaged in specific parts of post-conflict state and institution-building, including the policy field and the security sector. ${ }^{11}$

The former center of power of the regime was called Rijal al-Khayma, best rendered by the phrase "men of the tent." Ever since the late Colonel was forced to abandon his anti-tribal politics after the first decade of his rule at the end of the 1970 s, for reasons of realpolitik he increasingly used tribal symbolism to function as a rallying point and to

10 For historical reasons there has been a slight penchant towards the application of tribal versus state criteria for resource allocation and conflict resolution, the two fundamental roles of any authority. See Lisa Anderson, "Tribe and State: Libyan Anomalies," in Tribes and State Formation in the Middle East, ed. Philip Khoury and Joseph Kostiner (Berkeley, CA: University of California Press, 1990).

11 See Thomas Huesken, "Tribal Political Culture and the Revolution in the Cyrenaica of Libya," conference paper presented to the Libyan Centre for Studies and Research, Doha (2012). 
cement his role as primus inter pares in the tribal logic. Next to his idiosyncratic attire that was inspired by tribal garb, he became famous for his state visits abroad in a nomadic tent. In this way Qadhafi appeared eccentric to the international community, but was sending signals of identity and belonging to his fellow countrymen.

In the new political system of democratic representation that Libya is currently experiencing as a work in progress, the tribal element will have to be accounted for. As a matter of fact, no purely tribal parties have been established, not even by the nation's largest tribal confederation, the Warfalla. Rather, tribal elements are represented in smaller parties that joined larger coalitions, or by individual candidates who can count on (parochial) kinship loyalties for a ticket to parliament. This could enable them to claim to represent the particular interests of certain tribes at the national level (e.g., in redistributive policies), under the premise of being part of a ruling coalition. Whether this method will be put into practice remains to be seen.

With a guaranteed regional partition of seats in the assembly (102 Tripolitania, 60 Cyrenaica, 29 Fezzan, and 9 Sirte) that represents voters solely by population density, without any other considerations, experts are warning against an institutionalization of tribal interests along the lines of the Afghan Loya Jirga. ${ }^{12}$ Such a mode of parallel representation would undermine the election-based democratization process, and thereby decrease the stability of the political system.

\section{Pluralism and Stability}

A main question mark, in particular from the perspective of external players, relating to the Arab uprisings touches on the nexus of political pluralism and stability. The Libyan example has shown that opting for democratic pluralism in the wake of NATO intervention need not result in chaos. Even the electoral process itself proceeded in an orderly fashion. If the winners of the elections can reach power-sharing agreements at the highest levels - such as an accepted repartition of ministerial portfolios - and are able to take into consideration eastern concerns (e.g., those formulated by the CTC) regarding their perception of continued marginalization, the political situation will gradually consolidate itself. In this manner the single most important prerequisites for the further centralization of power - namely, the institution of trust and of a central authority — via security sector reform and disarmament, demobilization, and reintegration (DDR) will be laid.

The results of the 7 July elections for party lists showed a very strong performance by Ahmed Jibril's platform, the NFA. In most of the electoral districts the political platform of the Muslim Brotherhood came in second, although quite often its support was separated from that for the NFA by a ratio of $1: 10 .{ }^{13}$ During the early counting, which indicated a strong show for Jibril's alliance, he extended an offer for a national dialogue to other competitors. Since these elections correspond to the second of several phases of

12 The Loya Jirga is an institutionalized political entity that exists to represent tribal interests in Afghanistan.

13 See Hussein Ibish, "A Patronizing Narrative Pigeonholes Arabs," NOW Lebanon (17 July 2012). 
democratization, and will result in yet another interim government, a platform for dialogue could bring on board potential spoilers and hinder the general acceptance of the constitution, which is going to be elaborated by sixty members of parliament.

The downside risks for the next government will be mainly linked to the question of militias. Even though various projects and programs for the reintegration of militia members into a newly democratic Libya are making progress (through DDR activities), the next steps by the elected government to disarm militias need to be more assertive than those of the quite reluctant NTC, who preferred to engage the issue by following the course of outsourcing training security personnel abroad, so as to avoid any direct confrontation with militias or their respective leaders. However, certain entrenched militias (in particular the large confederations) could challenge a more determined stance.

The historic importance and symbolism of the elections cannot be overstated. They represent a novelty in themselves and, despite (or probably rather due to) the religiously conservative nature of Libyan society, Libya did not follow the trend of political Islam like in Egypt. With unclear majorities still to be negotiated, and the NFA representing a potentially volatile bloc of dozens of smaller groups, political instability could persist for a while.

However, electing a new government is only one step on a long, probably rocky road to a stable and safe Libya following NATO's Responsibility to Protect (R2P) intervention. Government administration needs professionalization, expectations towards the role of the (patrimonial) state management need to be reshaped (in particular those of the numerous and unskilled youth), and, last but not least, the entire security sector requires a concerted redesign to reintegrate loose militias into civilian life or into a professional career in the armed services under state authority.

In post-OUP Libya, the major challenges facing the government in Tripoli can be summed up as follows:

- Regions fearing a continuation of their previous marginalization (in particular Cyrenaica) expect clear signs from the central government that the distribution of resource-based wealth, including tax revenue, will be more equitable.

- Militias (kata' $i b)$ need to be disarmed and reintegrated as quickly as possible to avoid an entrenchment of their positions.

- The economy needs diversification into the non-oil sector to attain sustainable growth and tackle the issue of massive youth unemployment.

- Border protection requires professional staff, training, and equipment, along with support from police to fight organized crime.

- Increasingly racist clashes in the south (Sebha and Kufra) need to be addressed and mediated with respect to the concerns of all conflicting parties.

\section{Libya's Security Sector: Reform and Governance}

The security sector under Colonel Qadhafi was characterized by a crippled regular army, powerful paramilitary brigades for the protection of the ruling elite, and a plethora of 
mukhabarat (intelligence and security services). ${ }^{14}$ In the armed forces, entirely chaotic purchase policies had led either to a lack of interoperability of the equipment or to inefficient deployment of materiel and personnel (e.g., too many reconnaissance and surveillance planes). In addition, the Libyan Army had been routed in the war with Chad in the 1980s, and the Minister of Defense was considered more of an internal threat than a supporter of the regime. Since Qadhafi-even though he was titular head of the armed forces - did not build up a reliable and supportive army (unlike the Baath regime in Syria), the inner circle of power was protected by elite brigades and security personnel hired through kinship ties. ${ }^{15}$ The former head of Libyan intelligence, Abdallah alSenussi, and his advisors, such as Ahmad Qadhaf ad-Damm (both now exiled in Mauritania and Egypt, respectively) had been appointed on the basis of their family ties.

The security vacuum that erupted briefly during the civil war and NATO's air campaign due to army defections, the defeat of elite brigades (e.g., Khamis al-Qadhafi's $32^{\text {nd }}$ Brigade), and the disappearance of police was effectively filled by locally-rooted militias. These groups are formally organized in Local Military Councils, which are more or less accountable to equally locally-rooted political-administrative Local Councils. They recruit from cities (e.g., Misrata), city-quarters (Suq al-Juma), or rural tribes (Zintani berbers), and effectively provide for the safety and security of populations or citizens in geographically limited spaces. In other words, the lack of a centrally organized and authorized security sector in Libya did not and does not equate to chaos, but rather the opposite. However, this situation is both good and bad. On the positive side, these armed former revolutionaries have successfully prevented the eruption of widespread chaos by remaining locally-bound actors; they have not sought to go adventuring elsewhere in the country. On the negative side, disarming militias and registering or destroying their weapons without offering an alternative security system or other professional opportunities to the former fighters will not increase security.

The current political process (elections, constitution drafting) should create trust and provide legitimate authority to the government. On this basis, the popular mood might slowly shift away from favoring local militias for the provision of security services and allow official bodies to replace the irregulars. A major challenge during the political transformation process will be meeting local expectations without undermining a blossoming central authority by devolving too much power to parochial interests.

The same is applicable to security matters, hence militias. In other words, only a combination of simultaneously offered occupational alternatives and the creation of a reliable, centrally driven security provider could enable a smooth process, avoiding the risk of recreating a dangerous security vacuum. An important point, hinting at the interdependence of political and security actors, is the Ikhwan's fear of the army, not only as a secular-oriented institution but also as a political opponent. Therefore, the Muslim

14 Hans-Peter Mattes, "Challenges to Security Sector Governance in the Middle East: the Libyan Case," DCAF Working Paper no. 144 (August 2004).

15 Moncef Ouannes, Militaires, Elites et Modernisation dans la Libye Contemporaine (Paris: L'Harmattan, 2009). 
Brotherhood will use every opportunity it can deploy through Libya's elected institutions to keep the army weak and their budget insignificant, thus further reducing the currently scanty appeal of the armed forces.

The United Nations, via UNSMIL (UN Special Mission in Libya), have been assigned a special role by leading the post-conflict stabilization planning and carrying the responsibility to coordinate all relevant actors. One of their tasks includes mediating between the Ministries of Interior and Defense, due to a lack of direct communication. ${ }^{16}$ A basic needs assessment for the security sector is currently under way, including the drafting a white paper that should define the roles and size of the police and military and define prioritized areas.

According to a high-ranking general who previously served in the army under Qadhafi and was among the first to defect, the future armed forces of Libya will have a set of priorities that it hopes to achieve:

- Modern, interoperable equipment (based on functional purchase decisions)

- Inclusion of motivated young soldiers to reverse the inverted age pyramid (former rebels are not favored as military enlistees, but are also not particularly interested)

- Border and territorial protection with state-of-the-art surveillance equipment

- Interest in further cooperation with NATO (based on the OUP success).

Overall, a crucial point to consider is determining a realistic timeframe for post-conflict stabilization. Domestic expectations, as well as those of external actors willing to engage in SSR/DDR or general institution building, should be framed in years, not months.

\section{A Fragmented, yet Stable Landscape}

With the official end of the "17 February Revolution" and of NATO's Operation Unified Protector almost a year ago, the Tripoli agglomeration is currently still controlled by a number of militias or mergers thereof. Despite this obvious lack of a state monopoly on violence, predictions of complete chaos in the wake of Qadhafi's fall have been falsified (or rather have turned out to be his very own propaganda). The main players in the capital are composed either of local neighborhood militias or those from nearby regions (Jebel Nafusa) and cities (Misrata), or ideology-based Islamist groups, who all poured in to liberate the city from forces that remained loyal to the regime in late August 2011.

Following Qadhafi's capture and execution, the military groups converging in Tripoli for the liberation of the capital set up three major alliances (tajammu), which still

16 The extremely hierarchical decision-making process under Qadhafi precluded horizontal communication within the government. In the current transitional period, this legacy seems to be complemented by tribal rivalries (the Ministry of Defense is led by a Zintani, the Ministry of Interior by a Misratan). 
remain in place and whose very existence has not been brought up as a major topic by the NTC. This reluctance is due on one hand to the Council's interim role, which undermines its authority, and simultaneously to the problem of shared revolutionary credentials of the NTC and the thuwwar, whereby any direct effort to disband the militias could be interpreted by the latter as a betrayal of the "goals of the revolution." Based on data retrieved by the Warriors' Affairs Committee $\left(\mathrm{WAC}^{17}\right)$, militias in Tripoli number an astounding 577, followed by Benghazi with 300. The towns of Sebha and Ajdabiya rank third, with 69 militias each. ${ }^{18}$

The "Western Military Council" is led by Mukhtar Fernana, a Zintani berber and a man seemingly without political ambitions. The group's backbone consists of at most 5,000 Zintani fighters, propped up by additional forces of various origin. Their area of control stretches from Tripoli as far south as Ghadames, at the Algerian border, making them one of the most powerful alliances. The "Tripoli Military Council," under the guidance of Abdelhakim Belhaj, a former LIFG fighter, is an ideology-based militant Islamist patchwork of likeminded jihadis. Nonetheless, Belhaj decided to opt for politics, and led the Watan (Nation) Party during the recent elections, where he scored quite poorly. Third, the "Tripoli Revolutionary Council" remains under the command of Abdullah Naqer al-Zintani. From February onwards he signaled willingness to cooperate with state authorities to support their programs for reintegrating former rebels. In addition to these large confederations, smaller militias hail from specific areas of the city, such as the "Katibat Shuqudh" from Suq al-Juma.

An additional major area of concern, besides their armaments, are the illegal detention centers operated by militias, which have often been transformed into a sort of raison d'être. It is estimated that more than 4000 detainees (mainly former loyalists) still remain in the custody of militia groups. ${ }^{19}$ For all the reasons mentioned, at some point realistic and enforceable deadlines will be necessary to disarm the militias and to transfer their detainees to the official judiciary system. The prerequisite for such a delicate task will be the establishment of a confirmed non-interim government, which in turn could persevere in its efforts to legalize the entire spectrum of the security sector.

\section{Rewinding the Proliferation of Arms and Kata'ib}

Clearly, tackling the issues of arms proliferation and the mushrooming of militias needs to be addressed in a comprehensive manner in order to enforce the central authority of the newly elected government and to produce safety and continuous stability in postconflict Libya. To this end, the new authorities have tested various methods, including arms registration (58,000 according to the WAC), arms exchange (money for weapons), and jobs for weapons (e.g., insertion into security services).

The Prime Minister's office of the NTC created the Warriors' Affairs Committee to address this issue. The WAC has registered former combatants and set up programs for

17 Set up under the Prime Minister's office.

18 These quite considerable numbers are based on a total number of 250,000 registered thuwwar.

19 See Libya: Rule of Law or Rule of Militias? 
their integration into the security services and the economy. Surprisingly, a substantial number of the 250,000 alleged former thuwwar have been included in their database. ${ }^{20}$ The underlying idea is an exchange of weapons for government jobs in order to create stability. In addition, the WAC is offering projects for small businesses and start-ups.

Despite the efforts made through the WAC, the interim government has been criticized - and rightly so - for missing a unique chance to disarm the rebels. The handing out of payments to former fighters for their contribution to the revolution was not linked to a request that weapons be surrendered in return. Most of the arms that are now readily available on the black and gray markets throughout Libya or are dispersed among the population originate from the looting of arms depots at abandoned military facilities and from import during the revolutionary upheaval. Due to the enforcement of an arms embargo, these arms were imported mainly as contraband in Eastern Libya under the auspices of a major local tribe that lives on both sides of the Libyan-Egyptian border.

In the meantime, certain types of weaponry (RPGs and lighter arms) fuel a lucrative export business, creating a toxic nexus between organized crime and jihadi militancy. And the disappearance of most daytime checkpoints throughout Tripoli does not equate to the militia's dissolution. As they become entrenched in their roles as security providers, they still have considerable potential to play a role, either as spoilers or stabilizers.

\section{The Role for External Actors: SSR and Capacity Building}

The UN has been assigned the role of a central coordinator in post-OUP Libya. ${ }^{21}$ The range of topics under its remit also includes mediation between the Ministry of Defense and the Ministry of Interior, who refuse to engage in direct communication, which seriously hampers SSR planning or activities. This untenable situation should normalize once the new post-election government replaces the interim ministries.

Police training in foreign countries has been picked as a favorite tool by the NTC to teach basic skills to those former thuwwar interested in joining the regular government forces. This policy will be continued, without doubt, under the elected government, since the presence of a general lack of skills represents a major impediment to the development of the new Libya and needs to be overcome with professional help from abroad. Based on recently signed cooperation agreements, several countries will conduct police training for Libyan recruits. The largest batch is due for Jordan, which is set to train 10,000 police officers. Yet, partially due to a lack of previous screening, a severe lack of discipline repeatedly surfaced in Jordan. This issue needs to be addressed by the authorities who choose trainees to be sent abroad.

20 The WAC confirmed that the figures do not correspond to the actual number of thuwwar. But the idea is to get a maximum of (armed) people off the streets and into the economy.

21 Hansjörg Strohmeyer, "Libyen nach Gaddafi - Die Vereinten Nationen unterstützen den Aufbauprozess," Vereinte Nationen 60:3 (2012): 99-105. 


\section{NATO, the Mediterranean, and Libya: Mission Accomplished?}

Colonel Qadhafi's ideologically-based opposition to 'Western' values created a legacy that is impossible to overcome only through Memoranda of Understanding, lip service to cooperation agreements, and intelligence sharing (or even the dismantling of the Libyan WMD program). Terrorist attacks against civilian airliners (the bombing of Pan Am Flight 103 over Lockerbie in 1988, and of UTA Flight 772 over the Sahara Desert in 1989); repeated hostage-taking (the imprisonment and torture of five Bulgarian nurses for eight years, and the 2010-11 taking of Swiss employees of ABB); support for Abu Sayyaf in the Philippines; and the deliberate shooting of a British police officer from a Libyan Embassy building in London in 1984 can not simply be 'regulated' by compensation payments, the eventual liberation of hostages, or the repatriation of embassy personnel.

Furthermore, Muammar Qadhafi repeatedly provoked the wrath of his Arab brethren, in particular from the moment when he decided to turn his back on his Arab fellows and to portray himself as the self-styled "King of Kings" of Africa. The verbal altercation with the Saudi Arabian King Abdullah at the 2009 Arab League summit in Doha certainly provoked a final, irrevocable rift. All in all, the international diplomatic and political normalization process initiated in 2003 could never come to a proper end as long as Qadhafi persevered in his efforts to uphold his idiosyncratic ideology, either domestically or internationally through contentious foreign policy positions.

NATO set up the Mediterranean Dialogue in 1994 primarily as a confidence-building tool between member states and the southern and eastern Mediterranean. ${ }^{22}$ Despite the initial participation of numerous North African countries, Libya remained a holdout. ${ }^{23}$ This stance was not subject to change even since the apparent thaw in 2003. Hence, without any indications of a NATO-Libya rapprochement, and with the Arab League, the GCC, and the African Union turning against the Colonel, ${ }^{24}$ the ground for a potential escalation had been set, which swiftly evolved into an R2P-intervention in 2011 when the Libyan uprising threatened to degenerate into mass killings by the regime.

Operation Unified Protector turned out to be an effective tool to protect the civilian population of Libya, and the current constructive democratic process seems to vouch for the rationale to intervene and to respond positively to the R2P call from the UN. Since

22 Pierre Razoux, "The NATO Mediterranean Dialogue at a Crossroads," NATO Defense College Research Paper no. 35 (Rome, April 2008); available at http://www.isn.ethz.ch/isn/ Digital-Library/Publications/Detail/?ots591=0C54E3B3-1E9C-BE1E-2C24-A6A8C7060233

\&lng=en\&id=55304. In spite of their respective concerns, it is remarkable that the dialogue did not cease to function since the effective collapse of the Middle East peace process.

23 Qadhafi, concerned about 'Western' interference in the region, went as far as threatening the launch of a jihad. See Gareth Winrow, Dialogue with the Mediterranean: The Role of NATO's Mediterranean Initiative (New York/London: Routledge, 2000), 173.

24 Hans-Peter Mattes, Russland, China und die afrikanischen Staaten: Das Ringen um eine Libyenpolitik (Hamburg: GIGA, 2011). 
the end of its military engagement, NATO has made several statements in the media in the context of Libya's evolving situation. The latest positive public statement by the Alliance was made in relation to the elections. Prior to that, it expressed support for the ICC and their request to free their four arrested lawyers. On two previous occasions the question of civilian casualties caused by NATO's Libya engagement had been raised, including the case of "lives lost at seas" due to purported inaction by NATO vessels in the port of Misrata. Therefore, from a Libyan perspective, the headlines have been rather negative, despite the general positive mood towards NATO's engagement, which is seen as effectively supporting the revolution against Qadhafi.

Western interests in North Africa beyond the economic realm tend to be heavily securitized. In addition to the ENP, the European Union looks at Libya through the "FRONTEX-lens," considering the country a major conduit for illegal immigration towards the "Schengen area." ${ }^{25}$ With developments in the Sahel region and southern Libya pointing in the direction of escalation and increased militancy by various actors, there may be an easy return in Brussels to the consolidation of familiar attitudes, instead of using the opportunity to establish a new working relationship with Tripoli. In the same vein, NATO could miss a unique opportunity to build upon a strongly increased positive perception of the Alliance in a particularly important region of the world. ${ }^{26}$

\section{You Break it, You Own it?}

In the Western perception, the war was the easy part. This view is not shared by Libyans. The civil war left deep psychological scars in the nation, and between 20-30,000 casualties. Only their sheer happiness at having freed themselves from Qadhafi's shackles has allowed many Libyans to look forward, instead of dwelling on the trauma of the war. Building a functional state will take at least five to ten years, and must prove to be a stepping-stone for democratic consolidation and (national) reconciliation.

Yet, a question remains unanswered. Does the engagement by the Alliance, or at least those members (and their Arab allies) active in OUP, translate into a moral or legal responsibility? The destruction of 440 heavily fortified ammunition depots by NATO combat sorties provides an example. The impacts created fallout in a huge radius (up to five kilometers) and left some munitions intact. Highly specialized expertise is required to defuse these ticking bombs, and is currently being provided by UNMAS (UN Mine Action Service). But is cleaning up the remnants of destroyed depots of ammunition that the Qadhafi regime would have used to kill Libyan citizens the responsibility of the Alliance?

Since the overall perception in Libya toward the Alliance appears to be positive at this point, NATO could decide to use this opportunity to raise its political and diplomatic profile beyond a purely military aspect. A means to achieve this goal could be the

${ }^{25}$ FRONTEX (short for frontières extérieures) is the EU agency for external border security.

${ }^{26}$ For a position arguing in favor of generally increased suspicion towards the West in the MENA region, see Sigrid Faath and Hans-Peter Mattes, Der Umgang der nordafrikanischen Staaten mit dem Machtwechsel in Libyen (Hamburg: Edition Wuquf, 2011). 
establishment of a local transition cell. Whereas its intervention in Afghanistan created deep-seated negative perceptions against NATO, developments in Libya present the single best opportunity to start from scratch, or at least to engage on a new path in the framework of the Mediterranean Dialogue. The so-called Arab Spring and the ensuing regime changes in the region might lead to a necessary re-evaluation of partnership relations with some Arab countries. Nevertheless, the Mediterranean Dialogue would be the natural platform for exchange with Libya.

\section{Regional Defense Cooperation and Security Architecture}

On the level of regional, south-south security cooperation, a great deal of movement has been apparent since the uprisings in North Africa initiated fundamental political change. For the time being, new cooperation agreements have been forged on a bilateral level. However, this does not exclude a future large-scale rapprochement on the regional level, such as initially foreseen by multilateral, regional groupings like the UAM (Union of the Arab Maghreb).

During the pasts months Libya has signed several bilateral military and security cooperation agreements with its neighbors, such as Tunisia and Algeria. These Maghreb countries are highly concerned by two developments that led to the signature of these agreements, even though at the time of signature the Libyan NTC was still in charge. The first concern was the flow of weapons exiting Libya, while the second was transnational jihadi activism. ${ }^{27}$ Last but not least, the interest to unite facing a common enemy - namely, Islamic fundamentalism or militancy, in its quest for political powerexists generally among more secular-oriented entities, such as North African militaries.

The UAM will hold its next summit in October, after a hiatus that has lasted for more than sixteen years, indicating the former foreign policy priorities of the strongmen who ruled their countries. But some of the major obstacles that must be overcome to achieve closer links between the Maghreb countries (e.g., the Western Sahara conflict) can not be laid entirely at the doorstep of the deposed rulers. Yet the current political climate of change might be more conducive to achieve a consensus on common objectives and policies. If the summit can create the political will to move forward, there is a slight chance that security and defense-related issues will not be excluded from future agendas.

On a still higher level, but on the basis of an existing and functional framework that has lately switched to an almost hyperactive mode, the League of Arab States in theory is also potentially capable of providing a regional, mainly Arab-driven security cooperation network. At the same time, even setting the agenda for a loose framework is a formidable task in the light of the highly diverging geopolitical agendas and priorities among the member countries. An escalation of the Sahel crisis could nonetheless trigger a common interest sufficiently substantial to engage in a more permanent approach to a shared path of security cooperation.

27 "Le Maghreb déterminé à s'unir face à l'insécurité dans la zone sahélienne," RFI (Radio France Internationale) (9 July 2012); "Libya Neighbours Approve Border Security Plan," Magharebia (13 March 2012). 
Depending on domestic political developments and a yet-to-be-defined Libyan security and defense strategy, the new government might opt for a practical level of engagement, continuing in the operationally driven, multilateral 5+5 Initiative. This would present the advantage of continuing an existing program (in place since 2004) without the necessity to take the more politically delicate decision to join NATO's Mediterranean Dialogue. $^{28}$

\section{Recommendations for NATO ${ }^{29}$}

Operation Unified Protector was significant not only as an out of area operation, but more importantly as NATO's first R2P mission in the Arab world. Its success could help counter intervention fatigue among Alliance members, particularly in the wake of its long engagement in Afghanistan. Yet a crucial question remains: Is the mission in Libya really accomplished? If yes, which shape could a future relationship between NATO and Libya take? In the final document sealing NATO's Chicago summit in May 2012, the Alliance reiterated its readiness to support Libya within the Mediterranean Dialogue framework: "We are ready to welcome Libya as a partner." ${ }^{30}$ Surely, this proposal needs to be transformed into action, by both sides, not only in order to address the high expectations of Libyan political decision makers but also to manage and, where necessary, rectify them. This task can only be performed successfully through a strategy geared toward Libyan decision makers, and directed at informing them about the purpose, capacities, and goals of the Alliance. Below are some of the key issues that will need to be addressed:

- Fears of colonialism. Despite a generally positive attitude toward NATO after OUP, fears of neo-colonialism persist in Libya. Therefore, any future involvement by NATO or individual allies should take into account both the high level of expectations following the 17 February Revolution (and maybe dampen them) as well as the strong quest for local ownership (despite the lack of skills). In practical terms, this means taking a low profile while providing requested technical expertise.

28 “Libya Returns to '5+5' Defence Meeting,” Magharebia (22 November 2011).

29 Based on author interviews in Tripoli, Libya, the NATO Defense College in Rome, and at NATO HQ in Brussels. The purpose of these recommendations is primarily to highlight options for the NATO-Libya relationship and does not address internal lessons learned of OUP for the Alliance.

30 "We welcome Libya's stated interest to deepen relations with the Alliance. We are ready to welcome Libya as a partner, if it so wishes. In that perspective, the MD is a natural framework for this partnership. We stand ready, if requested, and on a case-by-case basis, to consider providing assistance to Libya in areas where NATO can add value. NATO's activities would focus primarily on security and defense sector reform, while taking into account other international efforts." NATO Chicago Summit Declaration, 20 May 2012; available at www.nato.int/ cps/en/natolive/official_texts_87593.htm?mode=pressrelease. 
- Pro-NATO momentum. Against the backdrop of the Alliance's generally low standing in the MENA region, it would be advisable to use the ongoing, surprisingly high levels of gratitude and positive feeling among generals and top militia leaders towards the Alliance to establish a solid NATO-Libya relationship. This can primarily be achieved via shared interests and common threat perceptions.

- Partnerships. Italy will endeavour to maintain strong ties with Libya for economic and security policy reasons. Therefore it could act as an interested facilitator to close the Mediterranean Dialogue gap. At the same time, the entire MD framework will need a basic overhaul to foster regional stability once the dust of the Arab Spring has settled.

- Communication. Set up, strengthen, and cultivate contacts with the new elected Prime Minister and the Ministry of Defense. Experiences and contacts from the "Libya Contact Group" may serve as a starting point or add-on. The goal of this political dialogue with the new elite, both civilian and military, should be to address mutual expectations and to define key issues of common interest (e.g., border security and anti-terrorism).

- Libyan National Army. Supporting the build-up of new army structures corresponds to helping with the establishment of a crucial element of the state's monopoly on violence. Where applicable, lessons learned from missions like NTM-I/II in Iraq could be incorporated into this effort.

- White paper. Propose professional support for the elaboration of an armed forces/defense strategy white paper. The knowledge resources of the Alliance can support the MoD with valuable insights on strategic and operational aspects of a centralized, national army.

- Libyan Staff College. Facilitate professionalization, cooperation, and exchange projects at HQs in Brussels or in Allies' capitals. In-depth exchange could be envisaged via participation in the NATO Regional Cooperation Course (NRCC) or the Senior Executive Regional Course (SERC) at the NATO Defense College.

- Special military training. Specialized training may be needed as a contribution to counter volatility in the southern, Saharan regions of Libya (Sebha, Kufra); to secure borders; and to fight the nexus of organised crime and jihadi terrorism (AQIM in the Sahel, and potentially global jihadis in Eastern Libya). For all these areas, Western technology and expertise will be required.

- Transition cell. The purpose of a local NATO transition cell in Tripoli would be to facilitate NATO-Libya communication and to function as an enabler for several of the recommendations in the current window of opportunity for enhanced relations.

- Public diplomacy. Such activities do not primarily require specific linguistic skills, but should build on cultural awareness to spark a genuine dialogue that 
avoids misperceptions. Visits of chosen counterparts (MoD/MoFA) to NATO HQ, NDC, or Naples would enable the Libyan military and diplomats to learn first-hand about the means and operational aspects of the Alliance.

- Implications for Syria. Avoid applying the Libyan R2P intervention model to the civil war in Syria. Syria's geopolitical setting, deep ethnic and religious rifts, and potential fallout of the conflict to regional neighbors require a different approach. 


\section{Bibliography}

Anderson, Lisa. "Tribe and State: Libyan Anomalies." In Tribes and State Formation in the Middle East. Berkeley, CA: University of California Press, 1990.

Ouannes, Moncef. Militaires, Elites et Modernisation dans la Libye Contemporaine . Paris: L'Harmattan, 2009.

Roberts, Hugh. "Who said Gaddafi had to go?" London Review of Books 33, no. 22 (2011): 8-18.

Strohmeyer, Hansjörg. "Libyen nach Gaddafi - Die Vereinten Nationen unterstützen den Auf-bauprozess." Vereinte Nationen 60, no. 3 (2012): 99-105.

Varvelli, Arturo. "Evoluzione della situazione in Libia ." Osservatorio di Politica Internationale: Approfondimento ISPI (2012).

Winrow, Gareth. Dialogue with the Mediterranean: The Role of NATO's Mediterranean Initiative . New York/London: Routledge, 2000. 